\title{
シリコーン油のフライ油劣化防止作用
}

薄木理一郎 ${ }^{*} \cdot$ 木 村 俊 明* $\cdot$ 金田 尚 志*

\section{The Effect of Silicone Oil on the Thermal Deterioration of Frying Oil}

\author{
RiIchiro Usuki*, Toshiaki Kimura* and Takashi Kaneda*
}

\begin{abstract}
It is known that silicone oil(SO) has a protective effect on the thermal deterioration of frying oil. However, little knowledge has been obtained of the mechanism of this effect. To know effect of SO, soybean oil with SO was heated. Heated oils were fractionated into 3 fractions by column chromatography and the chemical characteristics of each fraction were determined. The results indicated that all the SOs used for the experiments showed some effects, especially 20 and $200 \mathrm{c} / \mathrm{s}$ silicone oils added at $10 \mathrm{ppm}$ to frying oils, showed better effect than other SOs. Any fraction separated from SO-added oil was not oxidized as much as control oil. But from these results, the authors notice that it is rather difficult to find out an specificity about the effect of so on the stability of frying oils.

(Received Oct. 14, 1977)
\end{abstract}

シリコーン油（以下 SO 之略す）の消泡勃果 は従来 から知られており, 食品添加物としての使用が認められ ている。SO はフライ油の熱重合を抑制する作用のある ことが古くから報告されていた1が，その後重合だけで でなく熱酸化防止作用を有することが経験的に知られる ようになった。そのため市肘天ぷら油には $2 \mathrm{ppm}$ 程度の SO を添加する場合が多い。

しかし，SO のフライ油劣化防止効果がいかなる作用 機楆によるかについては諸説があり未だ明かでない。す なわち, 油面への SO の単分子膜形成による油之空気 との接触遮断(1) - フ 材質の活性表面被覆”などの推測がなされているが，い ずれも食用油と SO の関係を実験的に証明したもので はない。

また一口に SO といっても重合度, 置換基の異なる ものなど多くの種類がある。さらに濃度によって効果が 異なり，数 $10 \mathrm{ppm}$ を越えて添加すると効果が减ずると されている24゙がこのことについても実験データをふく
む報告はない。 そこで著者らは最も勃果ある SO の重合度(粘度)と 濃度を決定すると共に, SO 添加フライ油の性状汃らSO のフライ油劣化防止作用の機構を明かにせんとして以下 の実験を行った。

\section{実 験 方 法}

\section{1. シリコーン油の添加}

半井化学製およびシグマ社製 dimethylpolysiloxane をへキサンに溶解し，抗酸化削および SO 無添加の大 豆白絞油に種々の濃度で添加した。

\section{2. 各種添加濃度における加熱試験}

一般に食品添加物としては 100〜350 センチストーク ス (c/s) の SO が使われているため, この範囲内に入 る $200 \mathrm{c} / \mathrm{s}$ のものを用い, 最適添加濃度について検討し た。すなわち，大豆油 $200 \mathrm{~g}$ に SO; $1,5,10,20$ お よび $30 \mathrm{ppm}$ 添加したものを $500 \mathrm{ml}$ 三角フラスコにと り，無添加大豆油を対照として $180^{\circ} \mathrm{C} ， 16$ 時間通気加

* 東北大学農学部食糧化学科（仙台市堤通雨宮町 1-1） Department of Food Chemistry, Faculty of Agriculture, Tohoku University. Amamiyamachi-Tsutsumidori, Sendai 
热した。通気は流量のほぼ等しい Pasteur capillary pipette と Air Pump を用い，装置の都合上，二回に分け て実験した。

とのようにして調製した加熱油の酸価，カルボニル 価)，平肉分子量および着色度を測定した。

3. 各種重合度のシリコーン油による加熱試験

粘度 $20,1000,12500 \mathrm{c} / \mathrm{s}$ のシグ マ社製 SO を $10 \mathrm{ppm}$ 添加して 2. と同様の加熱試験を行い, SO の重合度の 差による添加効果の差の有無を検討した。

\section{4. フライ試験}

SO の添加勏果が実際のフライ時にもみられるかどう かを知るためじゃがいものフライ試験を行った。大豆油 $2 \mathrm{~kg}$ を直径 $22 \mathrm{~cm}$, 高さ $12 \mathrm{~cm}$ のホーロー鍋に入れ, $180^{\circ} \mathrm{C} て ゙ 10$ 時間揚げた。じゃがいも（水分 76\%）はポテ トチッブ程度に薄く切り， 1 時間に $700 \mathrm{~g}$ の割合で計 7 $\mathrm{kg}$ をフライした。試験は SOを $5,10,20 \mathrm{ppm}$ 添加し た油および無添加油の 4 種について行った。

\section{5. 加熱油およびフライ油の分画}

重合物の構造や性状が SO によって差異が生じるか否 かを知るため, $10 \mathrm{ppm}$ 添加加熱油, $10 \mathrm{ppm}$ 添加フライ 油，無添加加熱油および無添加フライ油の 4 種類につい てケイ酸カラムクロマトク゚ラフィーを行った。太田らの 実験6に潐じ，15\%および60\%インプロピルェーテル含 有n一キサン，エチルエーテルの 3 種溶媒にて展開し， 末变化トリグリセリド，重合物，二次酸化生成物と思わ れる3区分に分画した。各フラクションの酸価（比色 法辛より換算)，ヨウ素価，ケン化価，カルボニル価，水 酸基量8)，共役ジェン量9)，平均分子量を測定した。

\section{結果と考察}

\section{1. 各理添加瀷度による加熱試験}

SO, $0 \sim 10 \mathrm{ppm}$ 添加時 の 加熱試験結果を Table 1 Expt. Iに示したが，いずれの濃度にも添加効果が認め られた。重合阻止勃果は $5 \mathrm{ppm}$ 以上の添加において認 められたが、特に SO に油の着色抑制奻果のあることが 初めて明らかとなった。

添加量をさらに增した実験 (Table 1 Expt. II) では, 酸価の差は認められなかったが、カルボニル価および平 均分子量加添加勃果は明らかである。しかし $10 \mathrm{ppm}$ 以上では勃果の増大は認めがたく，このような実験条件 下では $10 \mathrm{ppm}$ 添加が最適のように思われた。

日本の食品衙生法は $50 \mathrm{ppm}$ まで消泡剂としての使用 を許可しているが，米国では $10 \mathrm{ppm}$ を越えてはならな い(10)とされており，添加SO のかなりの部分が揚げ種に
Table 1. Chemical characteristics of heated oil with or without silicone oil

\begin{tabular}{|c|c|c|c|c|c|}
\hline & $\begin{array}{l}\text { Level of } \\
\text { silicone oil }\end{array}$ & A.V. & Co.V.* & MMW** & O.D. ${ }^{* * * *}$ \\
\hline \multirow{4}{*}{ 壱 } & 0 ppm & 0.50 & 290 & 1042 & 0.414 \\
\hline & 1 & 0.48 & 196 & 1030 & 0.252 \\
\hline & 5 & 0.48 & 192 & 998 & 0.368 \\
\hline & 10 & 0.34 & 199 & 952 & 0.275 \\
\hline \multirow{4}{*}{$\begin{array}{l}\text { 口 } \\
\text { 莒 } \\
\text { 品 }\end{array}$} & 0 & 0.65 & 177 & 1053 & 0.490 \\
\hline & 10 & 0.67 & 127 & 946 & 0.096 \\
\hline & 20 & 0.41 & 128 & 977 & 0.469 \\
\hline & 30 & 0.65 & 115 & 981 & 0.233 \\
\hline
\end{tabular}

* Meq/kg

** Mean molecular weight

*** Optical density was measured at $460 \mathrm{~nm}$ in Expt. I, and at $450 \mathrm{~nm}$ in Expt. 11 .

吸着される゙)ととから，食品衛生的にみても高浱度 SO 添加は望ましくないといえる。富田4) は「添加量は $1 \mathrm{ppm}$ 前後が通当で，多過ぎると逆呩果をきたす」と報告して

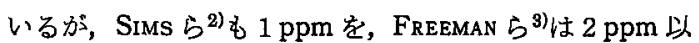
下を推奖している。添加勃果は添加方法, 加熱条件 (時 間，温度，通気や水分の有無，揭げ種）によって異なる と思われるが，1〜10 ppm の間であれば一応の添加勃果 を生ずると考えられた。

\section{2. 各種重合度のシリコーン油による加熱試娩}

Table 2 に示したように, 3 種の $\mathrm{SO}$ 中, $20 \mathrm{c} / \mathrm{s}$ に比較 的その効果を認めたが，1000および $12500 \mathrm{c} / \mathrm{s}$ にははと んど効果がなく，特に重合阻止作用は全然認められなか った。200 c/sのデータは Table 1のもので単純な比較 はできないが, $20 \mathrm{c} / \mathrm{s}$ と同程度の㸚果があるように思わ れた。

重合度が増すと油に対するSO の溶解度が隇るので， 高重合度 SO の添加濃度を变えた場合, 勃果がどう变わ

Table 2. Relationship between the characteristics of heated oil and the viscosity of silicone oil added

\begin{tabular}{ccccc}
\hline \hline Viscosity & A.V. & CO.V. & MMW & O.D.* \\
\hline $0 \mathrm{c} / \mathrm{s}$ & 0.43 & 204 & 1039 & 0.429 \\
20 & 0.52 & 151 & 952 & 0.157 \\
1000 & 0.34 & 173 & 1037 & 0.440 \\
12500 & 0.44 & 166 & 1008 & 0.211 \\
$(200$ & 0.67 & 127 & 946 & $-)$ \\
\hline
\end{tabular}

* at $470 \mathrm{~nm}$ 
るかわからないが，食品添加物として用いられている SO は 100 350 c/s なので, やはり $200 \mathrm{c} / \mathrm{s} の \mathrm{SO} の$ 使 用が適当と考える。

Table 3. Chemical characteristics of potato fried oil with or without silicone oil

\begin{tabular}{ccccc}
\hline \hline $\begin{array}{l}\text { Concentration } \\
\text { of silicone oil }\end{array}$ & A.V. & Co.V. & MMW & O.D.* \\
\hline $0 \mathrm{ppm}$ & 0.14 & 36.7 & 876 & 0.461 \\
5 & 0.12 & 13.6 & 868 & 0.236 \\
10 & 0.12 & 13.6 & 856 & 0.207 \\
20 & 0.12 & 15.1 & 871 & 0.186 \\
\hline
\end{tabular}

* at $430 \mathrm{~nm}$

\section{3. フライ試験}

加熱終了の 10 時間に近い油でフライしたポテトチッ プは着色む強く, ベとついてもはや商品価値のないるの であったが, Table 3 に示すごとく，油の少化はとれ程 進行していなかった。そのためSO 添加による差異は大 きくなかったが, $10 \mathrm{ppm}$ 添加ではやや良好な傾向を示 し，揚げ種のない場合（Table 1 )と同様であった。

4. 加熱油およびフライ油のケイ酸カラムによる分画 Table $4 k 10$ ppm 添加（十SO）加熱油の 分画区分の 各特数を無添加（一SO）加熱油のそれと比較して示し た。添加油は無添加油に比べ未変化トリグリセリドであ る Fr. 1 の量が 15.2\%む多く，逆にボリマーおよび極 性物質を含むFr. 3 が非常に少ない。この結果は他の特 数值とよく相関しており，特に酸価，ヨウ素価，カルボ ニル価, 平均分子量に顕著な差巽が認められた。
じゃがいもフライ油についても同様の分画を行った (Table 5 )が，加熱油よりも着色の程度がやや強いにも かかわらず，あまり熱酸化が進行していなかったため， Fr. 2，Fr. 3 の収量は少なく測定不能の項目を生じた。 しかし各区分共にSOの添加効果が涊められ，差は小さ いがその傾向は加熱油の場合と同様であった。

本実験は「官能基の指標となりうる諸特数中，一つの 分画区分でも添加による顯著な差異が認められれば， SO の作用機序の解明のための示唆を与えるのではない か」との発想で行ったものだが,加熱油, フライ油共に; また各分画区分共に，測定特数の全般にわたり添加効果 が認められた。このことはSOの教果が単に「重合を阻 止する」とか「加水分解を抑制する」とかいう単純な働 きをしているのではなく，一種の抗酸化刘ともいえる奻 果を有することを示している。

SO が油表面に単分子膜を形成して空気と油の接触を 遮断するという単分子膜説は多くの研究者によって支持 されているが, SO の酸素透過率が油のそれより大きい こと ${ }^{11)}$ や溶存酸素量が SO 添加の場合の方が高いこと ${ }^{12)}$ などから疑問が生じる。本実験のように強力に通気挖汼 した際には静置加熱の場合と状態が異ってくるのではな いかと考えられる。そこで SO の撥水性が閣題となって くる。太田ら ${ }^{12)}$ はSO の添加油の水分含量を加熱時閒と ともに追っているが，添加油が無添加油に比べてはるか に水分含量が少ないことを明かにしている。この影讋は フライ時に大きく現れると思われ，揚げ油の加水分解を 減少させると同時に，掦げ種より生じた水蒸気が一種の 不活性ガスとなって油面を覆い,酸素浱度を低下させ，そ の結果揚げ油の熱酸化定漣らせる(13)ことが考えられる。

Table 4. Chemical characteristics of three fractions separated from thermally oxidized oils with or without silicone oil at $10 \mathrm{ppm}$ level.

\begin{tabular}{|c|c|c|c|c|c|c|c|c|}
\hline & \multicolumn{2}{|c|}{ Oil before separation } & \multicolumn{2}{|c|}{ Fr. 1} & \multicolumn{2}{|c|}{ Fr. 2} & \multicolumn{2}{|c|}{ Fr. 3} \\
\hline & - So & +SO & - so & + So & - so & + So & - so & +SO \\
\hline Yield (\%) & & & 45.9 & 61.1 & 20.5 & 20.6 & 32.5 & 18.3 \\
\hline Appearance & Orange & Yellow & Colorless & Colorless & Yellow & Yellow & $\begin{array}{c}\text { Reddish } \\
\text { orange }\end{array}$ & $\begin{array}{c}\text { Reddish } \\
\text { orange }\end{array}$ \\
\hline A.V. & 1.12 & 0.72 & 0.14 & 0.07 & 1.10 & 1.23 & 3.32 & 5.03 \\
\hline S. V. & 199 & 191 & 182 & 182 & 197 & 194 & 211 & 211 \\
\hline I. V. & 107 & 115 & 116 & 124 & 107 & 108 & 95 & 73 \\
\hline Hydroxyl (\%) & 0.56 & 0.49 & 0.03 & 0.08 & 0.44 & 0.68 & 1.23 & 1.81 \\
\hline co.v. & 177 & 127 & 3.4 & 3.3 & 240 & 220 & 517 & 284 \\
\hline Conjugated diene $(\%)$ & 3.99 & 3.47 & 0.55 & 0.43 & 7.47 & 9.75 & 6.80 & 5.97 \\
\hline MMW & 1053 & 946 & 880 & 860 & 1216 & $\$ 194$ & 1611 & 1359 \\
\hline
\end{tabular}

* Three fractions were obtained by silicic acid column chromatography ${ }^{\circ}$. 
Teble 5. Chemical characteristics of three fractions separated from potato fried oils with or without silicone oil at $10 \mathrm{ppm}$ level.

\begin{tabular}{|c|c|c|c|c|c|c|c|c|}
\hline & \multicolumn{2}{|c|}{ Oir before separation } & \multicolumn{2}{|c|}{ Fr. 1} & \multicolumn{2}{|c|}{ Fr. 2} & \multicolumn{2}{|c|}{ Fr. 3} \\
\hline & $-\mathrm{SO}$ & $+\mathbf{S O}$ & $-\mathrm{SO}$ & +SO & $-\mathrm{SO}$ & $+\mathrm{SO}$ & $-\mathrm{SO}$ & $+\mathrm{SO}$ \\
\hline Yield (\%) & & & 83.5 & 90.4 & 12.6 & 6.7 & 3.6 & 2.7 \\
\hline Appearance & Orange & $\begin{array}{c}\text { Yellowisn } \\
\text { orange }\end{array}$ & $\begin{array}{l}\text { Light } \\
\text { yellow }\end{array}$ & $\begin{array}{l}\text { Light } \\
\text { yellow }\end{array}$ & $\begin{array}{l}\text { Yellowish } \\
\text { Orange }\end{array}$ & Orange & $\begin{array}{c}\text { Reddish } \\
\text { orange }\end{array}$ & $\begin{array}{l}\text { Reddish } \\
\text { orange }\end{array}$ \\
\hline A.V. & 0.42 & 0.29 & 0.12 & 0.11 & 2.63 & 3.47 & - & - \\
\hline S. V. & 192 & 190 & 184 & 184 & - & - & - & - \\
\hline I. V. & 119 & 128 & 128 & 131 & 117 & 112 & 113 & - \\
\hline Hydroxyl (\%) & 0.20 & 0.21 & 0 & 0.04 & 0.73 & 0.86 & 5.24 & 2.70 \\
\hline Co.v. & 36.7 & 13.6 & 2.1 & 2.3 & 229 & 192 & 493 & 358 \\
\hline Conjugated diene (\%) & 1.67 & 1.00 & 0.68 & 0.64 & 9.07 & 6.84 & 6.28 & 5.45 \\
\hline MMW & 876 & 856 & 857 & 846 & 1033 & 922 & 1078 & 971 \\
\hline
\end{tabular}

FreEMAN ら ${ }^{3)} や$ Rock ら ${ }^{14)}$ はSO が油の対流を抑止し て酸化を抑えていると述べている。これらSO の作用に ついての諸説は各々の実験について一応妥当な説明とい える。しかしSO の作用は一つの説明では包括できない 多様性をむっており，種々の加熱条件の中でさまざまに 㚪き，全体として熱酸化を抑えていると考劣るのが妥当 でないかと思う。

$$
\text { 要 約 }
$$

シリコーン油（SO）の示すフライ油劣化防止奻果の 作用機構を知る目的で SO を大豆油に添加, 添加濃度, 重合度 (粘度), 加熱油の性状について検討し，つぎの結 果安得た。

（1） $180^{\circ} \mathrm{C} て ゙ の$ 通気加熱，およびじゃがいもフライ時 とも，添加濃度は $10 \mathrm{ppm}$ が適当と思われた。

(2) $20,200,1000,12500$ センチストークス (c/s) の 4 種の SO 中, 20 および $200 \mathrm{c} / \mathrm{s}$ の両者により大きな 効果を認めた。

（3）加熱油およびフライ油をケイ酸カラムクロマト で分画し，その特数を各々の無添加油の分画区分と比較 したところ, 各区分とす酸化の遅延を表わす特数值を示 していたが，特にSO 添加による顕著な変化は認めがた かった。これまでいわれているSO の種々の作用が各々 に働き,全体として熱酸化を抑えているように思われた。

\section{文 献}

1) Martin, J. B.: U.S. Patent, 2,634,213 (1953).

2) Sims, R. J., Fioriti, J. A., and KanUK, M. J.: Lipids, 8, 337 (1973).

3) Freeman, I. P., Padley, F. B., and Sheppard, W. L.: J. Am. Oil Chem. Soc., 50, 101 (1973).

4) 富田 盛: 油化学, 23, 333 (1974).

5) 熊沢 恒-大山 保: 油化学, 14, 167 (1965).

6) 太田静行 - 岩田面樹 - 向井 明- 森田昌治: 油化 学, 13, 595 (1964).

7) Duncomвe, W.G.: Biochem. J., 88, 7 (1963).

8) 有機微量分析研究愁談会編: 有機微量分析（南江 堂), p. 452 (1969).

9）日本油化学協会編：基準油脂分析試駼法（朝倉書 店), p. 180 (1966).

10) U.S. Amendment Published in the Federal Register, December 2, 34 F.R., 1973.

11）太田静行・日下兵爾：第 13 回油化学討論会予稿 集, p. 68 (1974).

12）太田静行 - 日下兵雨 - 飛松少孝：第 14 回油化学 討論会予稿集 p. 34 (1976).

13) Peled, M., Gutfinger, T., and Letan, A.: $J$. Sci. Food Agric., 26, 1655 (1975).

14) Rock, S. P., Fisher, L., and Roth, H.: J. Am. Oil Chem. Soc., 44, 102A (1967).

〔昭和 52 年 10 月 14 日受理〕 